\title{
ORCID Identification: Importance as an Author.
}

\author{
Dr. Md. Ashif lqbal ${ }^{1 *}$
}

\begin{abstract}
AFFILIATION:
1. Dr. Md. Ashif Iqbal

Associate Professor \& Head

Dept. of Periodontology \& Oral pathology

Update Dental College \& Hospital
\end{abstract}

\section{Article info.}

Received: $29^{\text {th }}$ December, 2018

Accepted: $15^{\text {th }}$ February, 2019

Volume: 9, Issue-2 October, 2019

DOI: https://doi.org/10.3329/updci.v9i2.43730



(c) Authors retain copyright and grant the journal right of first publication with the work simultaneously licensed under Creative Commons Attribution License CC - BY 4.0 that allows others to share the work with an acknowledgment of the work's authorship and initial publication in this journal.

https://creativecommons.org/licenses/by/4.0/

Publisher: Update Dental College, Dhaka, Bangladesh

Web: www.updatedentalcollege.edu.bd

E-mail: updcj@hotmail.com

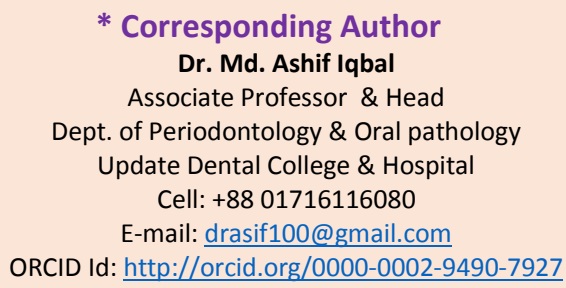

\section{Citation}

Dr. Md. Ashif Iqbal, ORCID Identification: Importance as a researcher. Update Dental College Journal. 2019 October; 9(2): 1-2 DOI: https://doi.org/10.3329/updcj.v9i2.43730

\section{INTRODUCTION:}

ORCID (Open Researcher and Contributor ID) is a global, freeto-use registry that provides research staff with unique persistent identifiers (ORCID IDs). Most immediately, ORCID makes a fundamental difference to a researcher's ability to gain full credit for their work as they track, evaluate, and publish research. As a researcher, it is vital to gain the full credit as a contributor or a researcher in your work. One of the best ways to gain this full credit is using an ORCID ID, and other benefits. Formally, ORCID iDs are specified as URIs, for example, the ORCID iD for me (Dr. Ashif labal) (iD is used in examples and testing) is ORCID Id: http://orcid.org/00000002-9490-7927 (both https:// and http:// forms are supported; However, some publishers use the short form, e.g. "ORCID: 0000-0002-9490-7927"

ORCID iDs are a subset of the International Standard Name Identifier (ISNI), under the auspices of the International Organization for Standardization (as ISO 27729), and the two organizations are cooperating. ISNI will uniquely identify contributors to books, television programs, and newspapers, and has reserved a block of identifiers for use by ORCID, in the range 0000-0001-5000-0007 to 0000-0003-5000-0001. It is therefore possible for a person to legitimately have both an ISNI and an ORCID iD - effectively, two ISNIs.

\section{WHAT DOES ORCID DO?}

With millions of researchers worldwide, it is inevitable that many of these will share the same name. Adding to this confusion, individuals may change their name at some point during their careers (for example, after one gets married), which may result in different variations of the same name. Therefore, it seems obvious that a researcher's name is simply not enough to identify an author of a paper or a dataset uploaded to a research repository. However, a unique identifier - as provided by an ORCID ID - works to ensure that links can be made accurately and efficiently irrespective of repeated names and name variations. As a result, James Smith from a research facility in Wessex can be uniquely identified as the author of his recent research paper published in Nature.

ORCID IDs are now embedded in most workflows, such as manuscript submission or grant application processes. As such, it has become a vital part of the metadata associated with research outputs, and ultimately reduces administrative burden for researchers. Universities and research facilities are encouraged to note the take-up of ORCID IDs due to their power to recognize researchers irrespective of who and where they are in the globe. 


\section{BENEFITS OF HAVING AN ORCID ID:}

1. Firstly, an ORCID ID provides the user with a unique number that will be used for the work on ORCID's database. This helps the researcher to gain the full credit on a paper, whether as an author or a contributor.

2. Secondly, it also helps the researcher's works to get discovered. Along with having connections on ORCID, this helps the work spread within the research community.

3. Another main advantage of ORCID is that it is a lifelong digital identifier; meaning that the work will always stay under the author's name and can always be accessed, even if the author gets out of the field later on.

4. Moreover, ORCID helps connect existing work from existing databases, so that the author has all his/her work in one place. An author can also have his page made public, in order to promote his/her work in the research community for users to benefit from them.

5. It's multidisciplinary; meaning that it does not focus only one scope of research, it is community-based; where you can have a community of researchers from the same field, and it has multiple languages. It also helps in the peer review for researchers with one another.

6. An ORCID ID is a major tool for researchers as it provides many benefits making it an essential part of their research journey.

7. Most reputed index journal wants ORCID iD of all Author's during submission of a manuscript or research work for publication.

\section{ORCID ID IN UPDATE DENTAL COLLEGE JOURNAL.}

Most of the Editors and Members of Update Dental College Journal uses ORCID iD for their personal identification in editorial team page of UpDCJ.

(https://www.banglajol.info/index.php/UpDCJ/about/editorialTeam) Within the manuscript we include the ORCID iD in their corresponding address if they submit. We trained our researcher and author's to use ORCID iD for their identification by trained up and open discussion of its benefits.

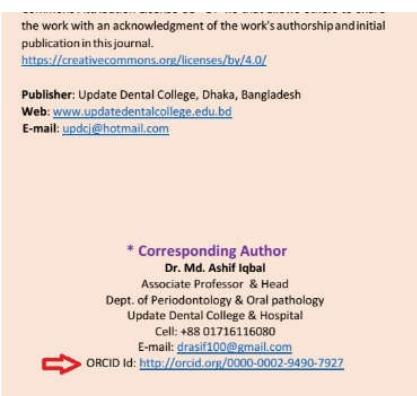

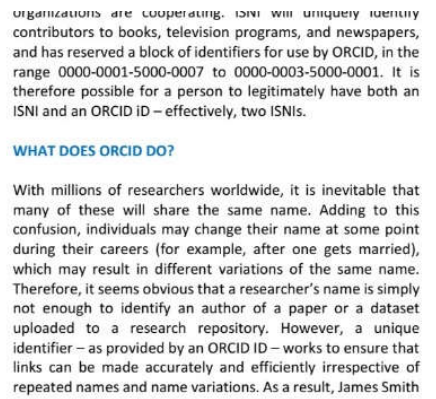
Including ORCID Id, in corresponding Author within the cover page of an article.
CONCLUSION:

One could be individual as a researcher or author by using ORCID iD and could solve different types of error made by the similar name. Even it could be use as personal profile page, which easily could be share for the professional work.

To know more and sign up for an ORCID ID, visit the following link https://orcid.org/register

https://www.youtube.com/watch?v=9cccd-Y9_Ww

https://www.youtube.com/watch?v=a1Rijk TMHA

\section{REFERENCES:}

1. https://orcid.org/register

2. https://edgeclinical.com/blog/2016/7/7/edge-users-and-theimportance-of-orcid-identification\#

3. https://www.ierek.com/news/index.php/2018/06/19/importanceorcid-id/

4. "Trademark and iD Display Guidelines". ORCID. 19 February 2013. Retrieved 21 August 2013.

5. "Structure of the ORCID Identifier". ORCID.

6. "Josiah Carberry". Biography. ORCID, Inc. Retrieved 22 December 2014. Josiah Carberry is a fictitious person.

7. Meadows, Alice (15 November 2017). "Announcing API 2.1 - ORCID iDs are now HTTPS!". ORCID. Retrieved 16 November 2017.

8. "Hiroshi Asakura". Hindawi Publishing Corporation. Retrieved 20 April 2014.

9. "Template ORCID". Wikipedia. Retrieved 16 February 2015.

10. "ISNI and ORCID". ISNI. Archived from the original on 4 March 2013. Retrieved 29 March 2013.

11. "What is the relationship between ISNI and ORCID?". Retrieved 23 October 2012.

12. "Structure of the ORCID Identifier". ORCID. Retrieved 23 July 2014. 